\title{
Footprints, Imprints: Seeing Environmentalist and Buddhist Marie Byles as an Eastern Australian
}

\author{
Allison Jane Cadzow, University of Technology, Sydney
}

This paper is a response to a challenge posed to me: to find ways of thinking of Australia as Asian, rather than an island culture tenaciously clinging to British ancestry and identification despite indigenous and Eastern influences. What different understandings of Australian lives and subjectivities might emerge when Australian lives are seen as Asian also? It seemed appropriate to undertake this experiment in thinking within the context of the life story of a figure who challenged easy definitions, spent much of her life between Asia and Australia and belongs to the histories of many places in the region and relationships between them. This paper uses historical, cultural and textual analysis to explore the life of Marie Byles, a significant conservationist and Buddhist, as simultaneously Eastern ${ }^{1}$ and Australian through her travel writing, her interpretations of Buddhist texts for English reading audiences, and her environmentalism.

\section{Background}

Marie Byles (1900-1979) is usually introduced with a string of roles trailing behind her name: pioneer feminist, early woman solicitor of 1920s, explorer and lone female traveller in late 1920s. It is often mentioned that she was an environmentalist, and, from

\footnotetext{
${ }^{1}$ The terms 'east' and 'eastern' are used in this essay to indicate a European-derived cultural perspective of an imagined 'Other' contrasting with the 'west,' rather than as literal, geographical descriptions.

PORTAL Journal of Multidisciplinary International Studies Vol. 4, no. 1 January 2007

ISSN: $1449-2490$

http://epress.lib.uts.edu.au/ojs/index.php/portal
} 
the 1940s onwards, a Buddhist. She helped to promote a similar version of herself in her unpublished autobiographical work, Many Lives in One. Born in England, she moved to a bushy area of northern Sydney, Australia with her parents and two brothers at the age of eleven, was raised by Unitarian and unorthodox parents. Her mother was a suffragette and artist, who encouraged her to be economically independent and to pursue her education, while her father was a Fabian socialist railway engineer who delivered criticism of private property, encouraging his children from a young age to chant ‘Down with the blasted landowners!' (Byles 1944, 2).

This brief background does not do justice to the connections between these elements of her life or her simultaneously international and Australian outlook. Although she was born in England in 1900 and lived in Australia for most of her life, Byles travelled through China, Burma and northern Vietnam in the 1930s, India in the 1950s, and Japan in 1960s, forming ongoing connections with these places. Her perspectives on the environment were profoundly shaped by Buddhist philosophy as well as by her experiences of Australian landscapes. Given that she was among the instigators behind the establishment of several national parks in Australia and a contributor to international debates on Buddhism and Gandhian thought, it seems important to value the relationship between place and ideas that animated her life and work.

Some studies of Byles's life broach her relationships with the region and Buddhist ideas. The documentary film by Gillian Coote, A Singular Woman (1985), has done much to arouse interest in her life and addresses her spirituality. Byles was celebrated in an exhibition at The National Trust of Australia (NSW) in conjunction with its 60th anniversary. ${ }^{2}$ She appeared in an anthology of Australian writing about the East, albeit briefly (Gerster 1995, 176-9), and in Paul Croucher’s epic history of Buddhism in Australia. These testimonies are invaluable in showing the richness of Byles's life and work, but there is certainly room for more thinking about her as at once Eastern and

\footnotetext{
${ }^{2}$ The exhibition Marie Byles: A Spirited Life was curated by Julie Peterson and drew heavily upon the research of myself, Gillian Coote and Julie Peterson as well as the contributions of numerous relatives and friends of Marie Byles. The exhibition toured Sydney, the N.S.W. Central Coast and Bathurst. $<$ http://www.nationaltrust.org.au/properties/ahmisa/default.asp>
} 
Australian, and about her ongoing relationship with Asia and its influence on her thinking.

In this paper I canvas one way of understanding the influence of spirituality, particularly on Byles's approach to the environment, by focusing on her life as an Eastern Australian. This term suggests her primary location for most of her life on the Eastern Australian seaboard, and also hints at differences within Australia due to its different environments, histories and communities interacting over time. Reflecting on Eastern Australian identities can encourage us to consider Australia in Asia, Australia as Asian, connections across oceans and time, looser groupings, and identifications that allow for movement. The term draws attention to the value of looking at how place is made through social connections in time and space, following feminist cultural geographer Doreen Massey’s work (1995). Edward Said’s insight that due to imperialism's influence on cultural exchange, no one is 'one pure thing' and that crosscultural connections enable survival, rather than a rigid insistence on sharp differences, is also relevant here (1993, 407-8).

By focussing on Byles's life and the historical and cultural context in which she lived, it is possible to highlight the complexities of so-called Anglo, Eastern and Australian identities. A close study enables consideration of connections and belongings, which are not necessarily ethnicity based, or dilettantish, and that thus cannot be dismissed simplistically as 'Orientalist.' It seems especially pertinent to argue this position against such reductive profiling as that directed at Lebanese Australians, Muslim people, and refugees in much popular debate in Australia today. In this paper, then, I look at four facets of Marie Byles’s life as an Eastern Australian: her travels in Australia and China; the design of her home in Sydney and its use as a hub for early Buddhist meetings; her publication of texts discussing Eastern philosophy; and her environmental activism. This is by no means a comprehensive look at her rich life and writings, or a detailed dissertation on Buddhist theology; rather, my aim is to point to some areas worthy of closer examination. 


\section{Marie Byles’s travels in Australia, China, Burma, Vietnam and Japan}

Marie Byles was fascinated by the east coast Australian bush from a young age and walked around Sydney’s bushlands with her family and with various clubs. She was an early member of groups like the Sydney Bush Walkers, which formed in the late 1920s as interest in recreation and conservation grew with industrialisation and as urban areas expanded into bushland. She wrote for newspapers and walking journals about her trips and took many photos, bringing these areas into wider Western knowledge networks. In her writing she promoted Australia as a worthy place to explore, proposing that the Australian landscape was lesser-known than the English landscape, and relatively unmapped and little known or valued in an Anglo-Australian society at the time. She also lobbied for the environmental protection of bush areas from the early 1930s, most notably in NSW (Cadzow 2002, 219-220).

Her major passion in her younger years, however, was finding 'real mountains' to climb. After climbing in Norway, England, Canada, and New Zealand in the late 1920s, as recorded in By Cargo Boat and Mountain (1931), she wanted to do another major trip. She started reading and planning for a trip to Yunnan, in South Western China near the border of Tibet, in the late 1930s. Her textual encounters with the East began there when her approach to travel as an educational experience took an Eastern turn.

She painstakingly organised an expedition to climb Mt Sanseto, with a group of women and men. As a consequence of wartime tensions and nearby fighting their route involved going through Burma to China. Before she arrived in China, geographical and cultural differences within Australia became more apparent to her. She took the train across the vast Nullarbor Plain in 1938 in order to board the boat heading overseas from Perth, and appears to have been surprised and disoriented by how different the west of Australia was from the east. This trip may have provided some of her earliest encounters with Aboriginal people rather than representations of them, and she was shocked by their poverty and, it seems, by their presence as well. Further north in Western Australia she noted the population comprised a 'League of Nations' (of mixed backgrounds). Her letters to her parents revealed the gulfs in middle-class Anglo 
understandings and knowledge about Australia's diversity and past, despite the claims of unified Anglo national identity promoted at the time (Byles, Papers 1914-1979). The experience also foreshadowed her limited experience and contact with Asian people, despite her efforts to research for the trip.

Byles dated her interest in eastern religion from her trip to Burma, before completing the climb. She was particularly interested in pagodas and shrines and stayed overnight in some of them (Byles 1963). She presented images of Chinese landscapes in walking magazines (which often made their way to British, Canadian and US walkers and environmentalists) and talks. The Sydney Morning Herald published her travel accounts, which partly funded the trip, thus contributing to the circulation of information in Australia about China. In these media articles, attention was drawn to the novelty of her expedition, not only as a woman mountaineer, but also as an Anglo-Australian interested in China. As Alison Broinowski (1996) points out, since the early twentieth century a steady stream of Australian artists, writers and commentators had been travelling to China, India and the eastern-Asian region, and bringing ideas and insights back into their own work and the country as a whole 6. Yet 'Asia' was still represented as exotic and 'Other,' and thus separate and distinct from popular Anglo conceptions of Australianness; this was compounded by fears of Japanese invasion during the Second World War (Broinowski 1996, 3, 14).

Some of Byles's comments might make a contemporary reader flinch, such as her attitudes towards local bargaining and the all too familiar juxtaposition of ancient China with the 'modern' west, which also occur in much western travel writing about the East (Byles 1939, 41). Nonetheless, Byles was aware that the activity of mountain climbing seemed unusual rather than laudable to Chinese people and noted uncomfortably that she was being watched as 'a pink-kneed animal.' The women on the trip adopted long blue Chinese gowns to avoid being 'stared at like animals in the zoo’ (1938b). Such self-consciousness and self -deprecation is remarked on by many analysts of British women’s travel writing, such as Sara Mills (1993, 22) and Alison Blunt (1994, 72-78) As they note, western women accustomed to being observed and subjected to the 'male 
gaze’ within their own culture were inevitably aware of their appearance and differential position in relation to men.

Marie Byles’s writing demonstrates her genuine interest and desire to learn about local people, and a willingness to adapt and adopt elements of cultural practice, which appealed to her. After her trip to China, Byles took to wearing Chinese clothing for comfort and practicality, including an outfit-deep blue pants and matching top-that she wore to work in her legal office in Sydney, and that aroused varied reactions among Sydney’s Anglo population (Sydney Morning Herald, 19 July 1938, 13). She tried to learn about the mountains and the climate around her in China, noting the presence of the 'black dragon,' the deity responsible for rain, and Mt. Sansato 'a great white dragon’ the snow clad 20, 000 foot mountain she aimed to climb (Byles 1939, 40-41). She seems to have developed a deep reverence for the mountains, as expressed in her dramatic description of the area:

Those peaks! Those knife edges of rock enfolded one within the other. How could one approach them, let alone climb them? I have seen mountains in Norway, Canada and New Zealand, but never anything to touch the icy inaccessibility of those virgin dragon queens whose serrated and ice covered walls protected them. For eight months of the year the winds howl around them and the snows drape them. For the other four their naked splendour is veiled in rain and mist which the Black Dragon hardly ever lifts. (Byles, Many Lives, Papers, 1914-1979, 119-120)

In contrast to other trips where she was more interested in mountains alone, this trip found her keen to learn about people, particularly the status of women and gender relations in the countries she visited (Byles 1940, 3). Unlike her other published accounts of travel overseas, there were more pictures of the people she met in towns and villages, and the guides they hired, such as Mr Shi who was in charge of their camp (1938c). Funerals, weddings, temples and family life featured in her images, and she showed interest in local religion. This could well be regarded as 'othering,' typical tourist behaviour and representation of other cultures as repositories of the spiritual to be tapped into at will by jaded Westerners. But more than this seemed to be occurring; she was being influenced and transformed by these experiences. She wrestled with her position as a traveller in China and local responses to her presence, mocked her own mixed-up instructions in broken Chinese, and was acutely aware of cultural differences 
when seeking accommodation and bargaining (1938c). Such trade and negotiation was not a purely financial transaction, but a form of cultural exchange as well.

Byles's accounts did not uniformly celebrate Britishness, although she occasionally cast herself as part of an exploratory people, in a pro-Empire celebration. Mixed with these 'bold British' moments was a fascination with the difference in gender relations elsewhere in the world, which is not surprising considering her interest in feminism. Among the Nashi people of China, she noted that the women did the physical work and were seen as strong, while the men remained at home caring for the children (1938b). She observed colonial divisions of labour in Haiphong, Vietnam, acerbically noting that the European women basically did nothing compared to their Vietnamese and Chinese counterparts (Byles 1940, 3).

The climbers finally made it to the base of the mountain and started an attempt on Mt Sansato after numerous delays. Snow and rain set in during a narrow window of climbing time and Byles was unable to reach the summit, leaving her 'bitterly disappointed.' She made sense of this failure by highlighting other discoveries (with the hindsight that autobiography allowed). She alluded to new ways of looking at situations in her descriptions and moved beyond the aim of climbing the mountain: 'What I had striven for and desired above all lay dead. I should never climb the mountain or feel again the touch of its rough limestone rocks...But the sun was still shining. There was something beyond the loves and sorrows of this world that had gone on through all the ages of geology. I did not understand; for the time being I left it at that' (Byles, Many Lives, Papers 1914-1979,126). After this she spent more time with her fellow climber Marj and the guides/muleteers, Wang and Magato. She taught them how to climb in what she described as 'gloriously happy' times, enjoying their company, especially their lack of arrogance compared to others in the party. Her mountaineering friend Dot Butler believed that the male climbers dominated the trip, much to Byles’s annoyance, 
as she liked to lead. ${ }^{3}$ In her autobiography she represented herself as learning from her guides’ conduct, admiring their smiling helpfulness and good temper, qualities she tried to develop within herself through meditation training (Byles, Many Lives, Papers 19141979, 121).

According to Byles, her 'ripening karma' took effect in Australia after this trip to China, in the 1940s. She became more interested in spirituality and started reading the Bhagavad Gita, the inspirational Sanksrit text central to Hinduism where paths to enlightenment such as devotion, meditation, action and knowledge and transcendence of Ego are discussed. This interest was accelerated by foot injuries she suffered in 1941, which curbed her walking, and forced her to find other ways of relating to the environment and herself (Byles 1963, 18).

Byles’s work thus became reflective and inward focussed, marked by shifts in her relationship to landscape in an attempt to cope with depression and illness, as she was not able to walk as easily. In a very fundamental way her trip to China sent her on another journey once home in Australia: it prompted a revision of self. In her own analysis, she attributed this to reaching mid-life and the reflections and questions it brought to the surface. In her later reflective work Paths to Inner Peace (1965, 12), Byles discussed this time of emergence from a confused and dark time to a calmer place: 'Inner peace is now becoming an increasingly real experience. The mountain peaks are still a very long way off, but the path is clear and sometimes even easy to follow.' Symbolically, what mountains and landscapes represented and meant to her changed; they became part of an intricate interplay of experience and thinking, with the place memorable for the experiences she had there rather than its aesthetic qualities alone (Riley 1992, 19). These experiences in China stimulated ongoing travels between Sydney and India, Burma, and Japan, as she sought further inspiration, meditation and guidance. Her struggles with her position as a westerner interested in Eastern philosophy, and her desire to share knowledge gained from this travel, emerge in print

\footnotetext{
${ }^{3}$ In a 1997 interview I conducted with Dot Butler, she said of the New Zealand men climbers on the China trip: 'they rather brow beat Marie when it came to getting out and exploring. They were the men and they were going to do it and I think Marie didn't enjoy that much.'
} 
in her various spiritualist works.

\section{Marie Byles’s Buddhist interpretations and engagements with Eastern spirituality}

When she returned from her China trip in 1939, Byles's reading of the teachings of

Buddha seems to have stirred her interest in explaining them for English reading audiences and local markets. Yet, there were certainly Buddhist influences afoot in Australia before Byles's work, as her own reading of Tasmanian F. L. Woodward's Some Sayings of the Buddha (1925) shows. Croucher's history draws attention to 1848 Chinese indentured labourers who worked in Australia and constructed joss houses, while Japanese pearlers in the north also practiced Buddhism. Buddhism was of interest to Anglo theosophists, especially from the late 1890s, and Singhalese Queenslanders were also selling Buddhist works (Croucher 1989, 2-5).

Like Woodward, with whom she corresponded, Byles was involved in interpreting and popularising information about Theravada Buddhism (based on the original teachings of Buddha about suffering and the means to alleviate it) for westerners who knew little about Buddhist practice and insights. She did this as a feminist from a particular position of valuing women's history and as a westerner with a Christian background. Byles was raised in a religiously tolerant environment, which she regarded as making her more open to Buddhism. She saw Buddhism’s rationality as a neat fit with science and modern ways of thinking, and set it alongside Christian insights, a tendency she shared with other western-based 'convert' Buddhists. Byles developed an enthusiasm for daily vipassana (breathing/'insight') meditation and yoga as part of her explorations of Buddhism. She also tried to live by the eight-fold path as prescribed by Buddha: right view, right resolve, right speech, right conduct, right livelihood, right effort, right mindfulness, right concentration (Spuler, 2003, xii). Byles’s Anglo-Australian interpretation of Buddhism marked a confluence of interests and practices, both western and eastern:

It has not been an easy journey. It might, or it might not, have been easier if I could have retired as a nun to the Sacred Hills of Burma. But even if this would have been easier, Westerners cannot do this, and no spiritual training or philosophy can have any value for us unless it can be put into practice amid the ordinary everyday life in which we find ourselves. That the practice and 
philosophy learned in Burma and Japan can be put into effect in the West, is what makes them important to us. (Byles 1965, 12)

Her interpretation suggested a valuing of difference but also of connections and adaptability. It is a version of Buddhism that incorporates, as well, the Eastern practices and principles of Theravada Buddhism, Western psychology, democratic and feminist principles, and features of Buddhism as practiced by Europeans in America (Spuler 2003, 2; Tsomo 1999, 28-9). She became keenly aware of the pitfalls of romanticising Eastern spirituality, drawing mocking attention to her initial obsession with finding an Indian swami or yogi who would show her a quick path to inner peace. An Indian colleague pointed out to her that an American artist, Earl Brewster, living in India had, by his example, richer spiritual guidance to offer than many of the yogis (Byles 1965, 207).

Such realisation came later. Her first substantial religious work in 1957 was Footprints of Gautama. It provided her interpretation of the adult/ministerial life of the Buddha, through the eyes of his disciples, both male and female. Byles went to north India in 1954 to research the book, visiting places where the Buddha had travelled after his enlightenment, and returned to Australia via Sri Lanka. The author of the foreword to Footprints, Lalita Rajapaske, Minister of Justice in Ceylon, who had guided other early Australian Buddhists, noted the particularity of Byles's feminist approach to Buddhism: 'Naturally, Miss Byles focuses attention on an aspect which a male is apt not to emphasise very much - namely the attitude of the Buddha towards women, and the part played by them in the development of the Dhamma' $(1957,12)$. Her work covered the conversions and contributions of women neglected in many interpretations of Buddhist texts—both Eastern and Western—which focussed on men's contributions. Figures such as Patacara, renowned for her knowledge of the rules of discipline, Bhadda, a talented debater, and Visakha, known for her generosity and munificence, are given due attention. Byles made sure women figures associated with the Buddha in his preaching life were mentioned and valued, rather than written out. This was in keeping with her recognition of women's work throughout her life, in the workplace and socially. This often took the practical form of acts like acknowledging the work of male 
mountaineers' wives in New Zealand, which allowed their partners to go climbing, and consciously employing single mothers and married women who needed economic independence in Sydney (Ronalds 2005).

The Buddhist women's stories and the lack of warfare in the name of the Buddhist religion appealed to both Byles’s feminist sensibilities and her pacifism, a linkage between long-held 'western’ interests and Buddhist philosophy. It was not always a benign and joyous experience of cultural exchange, however. She noted that monks tended to 'belittle' women in their interpretation of the Buddha's words, something she attempted to redress in her own work $(1957,14)$. Indeed, Byles mounted a sharp critique of the sexism apparent in monk worship, which clashed with her firmly held belief in gender equality:

All this monk-worship and nun servility would be merely a source of amusement to the tourist...The western man, even though a meditator, would probably hardly have noticed it unless he were very unusual. But when you are a woman mediator and a member of the servile community, you notice it very much indeed. And when you have been trained to abhor sex and class superiorities the abhorrence upsets your equilibrium and causes pain. (Byles 1962,110)

A review of Footprints in the journal World Buddhism by Margaret Barr, a Buddhist practising in India, suggested that Byles's work should be appreciated for the all too rare attention paid to women's importance in Buddhism, as well as its accessibility for Westerners interested in discovering more about Buddha (Barr 1960).

Byles’s writings indicate her importance in Australia and beyond in terms of debates and interpretation of Buddhism. She stated that she wrote for 'ordinary' readers, and provided further references for self-guided study on how to end suffering, encouraging readers to seek out the translations themselves (Byles 1957, 14-15). She also included a guide to the eight-fold path as an entry point into Buddhist principles and practice for curious readers. Some scholars, such as Anagarkia Sugatananda, disputed her understanding of Buddhism, arguing that she made the typical westerners' mistake of reducing Buddhism to a system of morality and diluting it (1960, 3). Local critics nonetheless recognised the value of her work in terms of its accessibility, even when 
they were dismissive of her writing style, or, in the case of the masculinist Bulletin, found her representation of Buddhism to be escapist and 'a submissive, feminine way of life’ (Terry 1962, 40).

Her books and articles in publications like Metta (Sydney), World Buddhism (Colombo), The Middle Way (London), and Gandhi Marg (New Delhi), as well as her discussions on spirituality on Sydney radio, reveal Byles's commitment to life-long learning beyond the academy, and her importance as a populariser of Buddhism. She contributed to debates on pacifism, interpretations of Buddha's insights, as well as Gandhi's work, through these journal and magazine publications, which also became part of a wider international and regional debate. She also corresponded with activists and scholars interested in Buddhist and Zen thinking, such as Thomas Merton in the U.S.A., regarding peaceful protests and anti-war activism. She left her mark on the lives of filmmakers like Gillian Coote and fellow walkers who became interested in Buddhism after discussions with her.

Byles further developed her investigations in The Lotus and the Spinning Wheel (1963), which examined the life of Buddha and his disciples' knowledge of him, and compared Buddha's life with that of Gandhi, exploring connections between their thinking. She saw both men as inspiring figures, but acknowledged that her interpretation of the links between them was highly personal, and not necessarily shared by other Buddhists. She pointed out features they shared, such as a focus on present life and the road to enlightenment, the latter in the Buddha's case requiring meditation and inner peace, for Gandhi consisting of good works, applied Buddhism, outward peace, and reforms. Byles concludes that a synthesis of both approaches was best for daily life guidance, and in order to connect philosophy and practice (252). Her interest in both leaders was shaped not only by her expeditions and the effects of her accident, but also by world events. Like several fellow walkers who were pacifists, she was deeply disturbed by the Second World War; the appeal of Buddhism at this time was partly a search for an end to war. She sought a shift of consciousness more broadly to eliminate the causes of warfare and violence. 
Byles travelled several times to complete meditations in Mandalay, Burma, which she narrated in Journey into Burmese Silence (1962) and numerous other works, beyond the scope of this paper, as is her trip to Japan where she starts to explore Zen and Ittoen ideas at Kyoto monasteries. This trip encouraged her to promote Tenko-San’s teachings in A New Road to Ancient Truth, published in English in 1969. Many of her later writings and articles argue for a synthesis of ideas and practices from many teachers and sources. Byles was not a slavish follower of any one tradition, which made her an outsider in many ways, yet also gave her a critical edge drawn from diverse perspectives. She seemed to tread the same steps and themes almost meditatively in her writing to convince herself and others of the merit of her findings: the value of loving kindness, humility, service, and the diminution of ego.

Byles’s journeys took her deep into ideas and connections with the Asian region. She provided interpretations of Buddha's life that valued women's contributions, and wrote comparative work about the philosophy of Gandhi and the Buddha for Australian and other English speaking readers. This work and her Eastern travel marked and shaped her environmental concerns, from regarding the Australian environments as her homesite and meditation space to her struggles for the preservation of bushland.

\section{Byles's Sydney home Ahimsa \& the Hut of the Happy Omen}

In a grounded and physical way, Byles's Eastern Australian approach is evident in her design and use of her home and property Ahimsa (taken from Gandhi's premise of nonviolence or harmlessness) in northern Sydney. In 1949 she enlisted the assistance of young Quakers (another religion in which she was interested) to help her construct the Hut of the Happy Omen, a large meditation hut built next to her home. The hut served as a place of quiet reflection accessible to like-minded people, but also demonstrated her public mindedness and ideas inspired by Buddhist and Ittoen notions of service to others.

As a co-founder of the Buddhist Society of NSW (1952) with Leo Berkeley, a London based bookseller who came to Australia in the 1940s, Byles offered her property for 
Society meetings and meditations (Croucher 1989, 32-33). By 1956 the group had grown to include 200 members, and had become a vital contact point, source of information, and a key organisation for Australian Buddhists that still flourishes today (1956, 3). Byles also supported one of the earliest visits of a Buddhist nun to Australia in 1951 when Anglo Australian Buddhism was in its formative stages. Sister Dharmmadinna, who had trained in what was then Ceylon, came to Sydney to present Buddhist practice and beliefs to European audiences (Adam 2000). Her stay with Byles was fraught with tension; she found Byles’s accommodation too Spartan, while Byles found her dogmatic.

Byles and interested Anglo contemporaries celebrated key events in the Buddhist calendar such as Vesak (Buddha’s birthday) and the moon ceremony (celebrated earlier by Buddhist Chinese Australian communities) at Ahimsa. This was well before the arrival of numerous Buddhist Vietnamese refugees in the 1970s and the subsequent mass multicultural public celebrations of the Tet and Moon festivals in Sydney's southwestern suburbs. For these practical steps in nurturing interest in Buddhist practice, as well as her writing, many Buddhist writers (Lyall, n.d.; Pearce 1981) regard her as a central figure in the establishment of European-based Buddhism in Australia today.

Byles’s property became a meeting place for those interested in Buddhism, for forging community, and for fostering debate. The property was a focal point for Sydney and NSW-based Buddhists and Byles helped to literally make a place for Buddhism in Sydney. She regarded Sydney bushland as an ideal place in which to meditate, and valued the interaction with other Buddhists:

\footnotetext{
For those who like peace and solitude Sydney is wonderfully situated, for it is surrounded by barren sandstone country unattractive to the farmer, so that within fifteen miles of what is spoken of as 'the second city of the Empire,' there are wild bushlands, or forested hills. In winter and spring they are sprinked with wildflowers and the air is filled with bird song. Probably our little group did not learn much about meditation, but the fellowship was good and also good was the practice of sitting still and being forced for a little while to try and quieten the busy intellect. (Byles 1963, 28)
}

Despite her reputation as a serious person, there were some light-hearted moments in 
her spiritual journeys too, including adventures with hatha yoga, where she fell out of difficult poses and almost landed in the fireplace of her hut.

Byles also attempted to establish other public places of reflection beyond her own home such as Buddhist retreats. She was involved in planning a retreat in Victoria in the late 1940s, which did not eventuate (Croucher 1989, 35, 56). Later she found land in northern Sydney and arranged for the Buddhist Society of NSW to purchase it in 1956. She did all the legal work for free, as with her work for national park preservation with Bouddi National Park, Garrawarra and numerous other bush places around Sydney.

On a more personal level, Byles recalled that it was 'a great delight' to return to Ahimsa after the disappointment of her Chinese mountain quest. She selected the land in 1937 before the China trip. Her passion for the Sydney sandstone bushland and knowledge of it is abundantly clear in the choice of location: high up on a ridge, dry and airy, with a garden brimming with plants native to the area. The house was oriented to capture the winter sun's warmth and light, and the windows invite the outside in, dissolving boundaries. Byles deliberately bought the bush land all around it so it couldn't be subdivided. Her creation of such a place marked her increasing attachment to Australian environments, which she had initially found alienating and disappointingly flat (Byles, Many Lives, Papers 1914-1979, 130). Today, Byles’s place makes a sharp visual contrast to many other blocks in northern suburbs where private property is celebrated with fortress style walls and hedges are designed to keep people out. It is still a place of quiet and retreat, and her generosity in giving it to the National Trust of Australia (NSW) has meant continuing public access to the hut.

Byles’s design of her home and approach to building (low maintenance and with minimal environmental impact) was part of a wider movement to live more in harmony with the Australian bush surroundings, and to foster better social relations (Stephenson 1999, 49). This movement was partly stimulated by Federation, urban expansion, and a growing number of non-indigenous Australians being born in Australia and spending much of their lives there. With some important exceptions, the Australian bush had 
been seen by invader-settlers to need taming and refashioning along British lines in what amounted to a kind of ecological imperialism; thus, valuing it as Byles did represented quite a departure (Griffiths 1997, 3). Byles was friends with Clare Stevenson and Stella James who had a Burley Griffin home designed for them in bushland on Sydney's northern beaches. According to Stephenson, the design of the Stella James house in Avalon reflected the relationship between these women as equal partners and their desire to fit in with their surroundings rather than dominate them $(1999,45)$.

Byles's pleasure in bushland dovetailed with her interest in simplicity and respect for nature that had been inspired by her interest in Eastern philosophy. She was deeply attached to her home, which seemed to nurture her sense of self as well as her thinking. Like several other women writers and artists of the time, as well as fellow walkers such as Dorothy Lawry, she drew a sense of strength and personal identity from her relationships with certain landscapes. Janice Monk and Vera Norwood found that women from a range of backgrounds in south-western USA were drawn to desert landscapes and felt liberated and creatively stimulated by them, in a way comparable to the relationship of Byles and other Australian women with east-coast bushland (Monk et al 1987, 229).

Byles’s attachment to the Australian bush was expressed through homesickness for the gum trees, scents and comforts of Ahimsa when she was in India (Byles 1963, 56). Yet her home and meditation bungalow at Binsar was held in similar esteem:

I have never had the slightest desire to acquire that 'proper house' and of all of my places I have stayed during my travels only the bungalow at Binsar in the Himalaya hills with its visions of snow peaks, could compare with the beauty of the bushlands seen from my own cottage. (Byles, Many Lives, Papers 1914-1979, 130)

It seems that she felt in some senses at least as 'at home' in parts of the East as she did in east-coast Australia (172). This sense of belonging to several homes at once thus raises questions about the complex connections between people and place and the motives on the part of people such as Byles to care for and look after those places. 
Byles was interested in the concept of sanctuary for herself, and other people, partly as a result of her interest in bushwalking and camping. This was an element of bushwalking she had always valued, but was less able to pursue after the accident. In setting up places for Buddhists to meet, there appears to be a convergence of her practice and approach; the very western practice of bushwalking to escape the city and industrialised society now met with an Eastern valuing of forests and mountains as sacred places for meditation and revelation, where people can be in harmony with nature (Cuc 1999, 71; Dinh 2003, 578).

\section{Marie Byles’s Eastern Australian environmentalism}

Perhaps Byles's most lasting legacy was her contribution to environmental debates. She had been interested in environmentalism and vegetarianism from a very early age, influenced by her mother and English traditions. As a child in Britain she had a keen interest in hiking, and later in the Romantic poetry of Wordsworth, Tennyson, Keats and Coleridge, which celebrated the natural world and spiritualism (Byles, Scrapbook). Living in Eastern Australia and witnessing changes to the environment around her increasingly shaped her views. She also drew upon her travel experiences, to promote protection strategies from her observations in Canada, USA, and England. Numerous walks in the Blue Mountains, west of Sydney, stimulated her desire to protect areas from roads and suburban encroachment, including what is now Bouddi National Park on the NSW Central Coast.

After the 1940s shifts and changes in Byles's approach to the Australian environment were evident, influenced by her accident, travels and increasing interest in spirituality. As the ways in which she could physically engage with her surroundings changed, so did her thinking about environments and the relationships of people with nature. Her writing for bushwalking magazines and newspapers became decidedly less recreation oriented, with fewer claims of 'discovery' and 'firsts,' and a greater emphasis on valuing of all living things (Cadzow 2002). 
In 1942, inspired by English writer H. G. Wells’s Modern Utopia, in which citizens spent seven days alone in the 'wild' without creature comforts in order to clear their minds and rejuvenate themselves, Byles spent a week in an isolated favourite camping spot at Kosciuszko, in the Snowy Mountains. She had few supplies: matches, a tent, compass, and a map. She went there not to walk or go 'peak-bagging' as before, but to meditate. She claimed it was hard but re-creative, and took immense pleasure in observing life around her, the chance to be still and think, and to escape news of the Second World War for a while:

Gradually, too, the world and its happenings got further and further away, and history passed like a cinematograph film to a god on Olympus. The hills with their knowledge of the last ice age, ten thousand years ago, took no account of empires - Babylonian, Roman, Spanish, British, German or Japanese, what did they matter? The only thing that counted and persisted in that cinematograph film, and grew as the years passed, was the little slender plant of human kindliness and helpfulness, and that had nothing to do with empires or wars. $(1942,36)$

Byles also adopted a cave near her brother's home in the Blue Mountains for meditation. She increasingly saw bush and forest landscapes as conducive to the reflection and inspiration celebrated in much Eastern and Romantic writing.

Buddhist influences on her environmentalism led her into opposition with Myles Dunphy, a key conservationist, mapmaker and walker. Despite their differences, they worked together on many environmental projects. Myles wanted to establish a Kosciuszko 'primitive area' with access for bushwalkers, while Byles regarded his ambition as selective and self-important (Meredith 1999,160). 'Primitive area' is a term that now seems very dated, but which is nonetheless revelatory. It suggests museumlike forests and landscapes, untouched by humans. These areas had, in fact, been managed by Aboriginal people for centuries. Aboriginal people were displaced and forced off the land around Sydney in places like the Burragorang Valley (a favourite spot for bushwalkers including Byles); their leases were often revoked in the twentieth century, and not earlier as is popularly imagined and suggested in many AngloAustralian histories (Goodall 1996, 123-24)

Byles argued that Myles Dunphy and his supporters had to agree to cater for all nature 
lovers, or exclude people altogether, because allowing people in would lead to expectations of infrastructural improvements, such as roads and toilets. She articulated and wrestled with some of the dilemmas facing non-Aboriginal Australians who were attempting to look after and preserve eastern Australian landscapes. The Federation of NSW Bush Walkers, a peak body, took her position; it valued nature and regarded the setting aside of such places as compensation to nature for other damage done:

the vast majority of bushwalkers have ruled that a primitive area must be for the wildlife which shall flourish there, not for our pleasure but for its own. After all, why should man in his arrogance say that primeval lands are of value only in so far as they subserve his ends? Is this not the vicious old profit motive coming out in another form? The Romans stripped the Dalmatian hills in quest of timber to build their empire. Kidman blasted a trail of ruin across Australia to build a fortune. It is true that people who want a primitive area only because it satisfies a human desire, would not ruin it like Kidman or the Romans, but their motives are the same, profit to themselves, mental or physical, if not material. (Byles 1945, 5)

In a blistering critique of capitalist and imperialist relations with the bush Byles argued that other living things had rights too. She questioned the elitist and people-centered approach of the Myles Dunphy position, which lobbied for 'wild' areas to be set aside primarily for bushwalkers. Byles was not against people using such areas to interact with nature; rather, as she explained it: 'Human beings will not be excluded from the primitive area but no facilities for entering it will be given, and the flowers may blossom and the kangaroos and wombats enjoy their lives there, whether any one sees them or not' $(1945,5)$. The influence of her Eastern travels is apparent in this reevaluation of her relationship with the bush and her understanding of the mountains as her teachers (Byles, Many Lives, Papers 1914-1979, 153). In other texts, such as 'Our Attitude to Nature,' she argued that Nature was a living entity like people, and thus ought not be treated as inanimate or existing solely for profit. This viewpoint was inspired by her consideration of Chinese and Vietnamese ideas of nature as inhabited by spirits (Byles, Papers 1914-1979, Box 1). In a similar vein, and with sharp foresight, she saw through the panic caused by the power of the atom bomb unleashed on Hiroshima; though horrified by it, she argued that the destruction of nature through clearing and 'the rape of nature' was more of a threat than the atom bomb.

Byles issued challenges to fellow walkers (who often considered themselves to form 
the environmentalist vanguard) in texts with deliberately challenging titles, such as 'Can Bushwalkers Save the Bush?' (Byles, Papers 1914-1979, Box 1). In this piece she argued that the destruction of nature came from the mind, suggesting that instead of asking 'do I want this,' people needed to ask 'do I need this,' and to recognise the interconnectedness of all life. She suggested that a shift in thinking was essential for a reduction of consumption and in order to address such problems as pollution and mining devastation. Byles thus defined herself clearly as an Eastern Australian environmental critic, pointing out that in places like Britain, the damage caused by sand mining and cement production was not as evident as in Australia, where national park areas were being reduced in order to increase mining revenue (Byles Papers, 1914-1979, 'Wanting Little’ Box 9). ${ }^{4}$ Byles critique of materialism connected with her Buddhist beliefs, which rejected the perpetuation of insatiable desire because of the ways it feeds suffering.

In other writings Byles debated the lofty claims of bushwalkers that the bush had intrinsic spiritual value. She asked whether it made a difference in terms of how those walkers engaged with life's struggles. She suggested learning from nature in order to apply Buddha’s wisdom of accepting suffering and seeking harmony with nature:

As I sat alone in the bush I wondered whether the forest had helped him [Buddha] find that wisdom. Perhaps it had. For natural things accept what life brings; they don't "want”; they play their part and pass on. And perhaps too, amid the vastness of nature the pettiness of our troubles falls into proper perspective... I do think that if we relax and let go and seek harmony with the natural things around, then Nature may be the goddess to us...Can the bush help us keep smiling? That is the test of its “spiritual value.” I think it can - if we let it! (Bona Dea 1945, 11)

Western writers before her like Thoreau and Whitman had investigated Eastern philosophy as an alternative to destructive thinking about the environment. Paradoxically, however, Eastern philosophy does not necessarily stop environmental damage in predominantly Buddhist nations, as Callicott and Ames point out (1989, 279, 286). Nonetheless, such ideas have been drawn upon in western contexts in conjunction with other arguments for greater care of environments. Some of Byles’s environmentalism stemmed from Western thinkers, but it took a decidedly Eastern turn

\footnotetext{
${ }^{4}$ This appears to be a reference to the Colong and Bouddi National Park (NSW) preservation campaigns.
} 
after the 1940s when her interest in Buddhism saw her revise her approach to life.

Croucher's epic and invaluable study of Buddhism in Australia points out that links between pacifism and a non-domination approach to the environment were crucial in the appeal of Buddhism to early Anglo-Australian naturalist writers. Croucher described Byles as writing works of 'Buddhist inspired ecology' and as being a soul mate of E.J. Banfield, a journalist and author of Confessions of a Beachcomber, who abandoned city life to become an environmentalist on Dunk Island in Queensland in the 1940s. Croucher connects both Banfield and Byles with the contemporary poetry of Robert Gray, which argued for acceptance of the Australian landscape as it was, as opposed to remaking it in a British or European mould (Croucher 1989, 86). As an English migrant to Australia, Byles struggled with nostalgia for the mountains, snow and shady forests of Britain. Initially she saw the Australian bush in terms of its lack; later she grew to value its unique offerings.

In addition to pacifism and Buddhism, Byles, and many of her fellow walkers, were also influenced by feminism as they developed gendered approaches to ecology. Various editors of the Sydney Bush Walker, and colleagues and friends of Byles, such as Dorothy Lawry, were very interested in writers like Thoreau and Whitman, as well as in the U.S. novelist Willa Cather, who queried the logic of profit and the ego driven relationships with nature (Lawry 1932, 12). Byles was part of a community of thinkers interested in these issues, a number of whom were feminists and critical of power relations in their own society. Convergences of Buddhism, feminism, pacifism, and early environmentalism, occurred in her writings about the Australian landscape.

\section{Conclusion}

Marie Byles explored complex connections and composite knowledges in her thinking and writings on travel and environmentalism. Examining her work afresh in an Australian and Asian context is a reminder that biologically and ethnically defined identities may overdetermine contemporary readings of past lives. Revisiting the work of Byles, and tracing her shifting positions and changing identity, is a case in point. 
Although she was deeply implicated in imperial and modernist thinking, Byles’s work also shows the possibilities of a broader, transnational humanitarian and intellectual framework and self-identification. Byles's approach was born of lived experience. She witnessed changes in the Australian bush and developed critiques of power relations from an entwining of feminist and socialist, pacifist and Buddhist/spiritualist revaluation of environments. From these influences she challenged her fellow walkers, environmentalists, other Buddhists, and society at large, to rethink their relationships with nature and each other. The significance of her writings, and the possibilities raised by her spiritual and environmental analyses, have yet to be valued sufficiently. This article barely touches on some of her insights.

In Footsteps Byles notes that the presence of the Buddha was once announced by his footprints, rather than by the statues that are so familiar today. Footprints is an appropriate image for someone as interested in bushwalking, travelling and spirituality as Marie Byles. The footprints' image suggests the 'take only photos, leave only footprints' mantra of recent eco-tourism, and a grounded connection with the earth, rather than separateness from it. The imprints of spiritual and ecological thinking can be traced through Byles’s life’s work, and provide intriguing directions for future explorations of Eastern Australian beliefs and environments, and for valuing the work of women in Asia as thinkers and activists.

\section{Acknowledgements}

This paper was originally delivered at the Women In Asia conference, UTS, 27 September 2005. Thank you to Dr Devleena Ghosh for posing the challenge of thinking Australia as Asian. Thanks are also due to Prof. Heather Goodall, Dr Denis Byrne, and Assoc. Prof. Stephen Wearing for many fruitful discussions about landscape, spirituality and migrancy. I am also grateful to friends and acquaintances of Marie Byles for discussing their memories of her with me and to the referees of this article for their suggestions.

\section{Reference List.}

Bona Dea, 1945,'If We Let It,' Sydney Bush Walker, 141, November, 11.

'News of the Month: Buddhist Centre in Australia,' 1956, World Buddhism, June, 3.

'Walking through China: Sydney Woman Realises Her Dream,' 1938, Sydney Morning Herald, 19 July, 13.

Adam, E. 2000, 'Buddhist Women in Australia,’ Journal of Global Buddhism, 1, 138-143 [Online] 
Available: http://www.globalbuddhism.org/1/adam001.html. Accessed 30 August 2005.

Adam, E. and P.J. Hughes. 1996, The Buddhists in Australia, edited by P. J. Hughes. Bureau of

Immigration, Multicultural and Population Research, Canberra.

'Australian Women Fact File: Marie Beuzeville Byles 1900-1979,' 2001, [online article], Available:

http://www.jessiestreetwomenslibrary.com/ Accessed 3 September 2005.

Barr, M. 1960, 'Quest for the Buddha and his Teaching' World Buddhism, April.

Blunt, A. 1994, Travel, Gender and Imperialism: Mary Kingsley and West Africa Guilford Press, London.

Broinowksi, A. 1996, The Yellow Lady: Australian Impressions of Asia, Oxford University Press, second edition, first published 1992.

Butler, D. 1997, Oral history interviewed by Allison Cadzow 25 September, Sydney.

Byles, M. B. Papers of Marie Beuzeville Byles, 1914-1979, ML MSS 3833 (13 boxes) Mitchell Library, Sydney.

Byles, M. B. Further papers 1923-1974. Add On 1932, (2 boxes) Pic Acc 4911, Mitchell Library, Sydney.

Byles, M.B. 1931, By Cargo Boat and Mountain, George Allen \& Unwin, London.

Byles M.B. 1938a, 'Town Gates Closed to Keep Out Evil Spirits: Sydney Woman’s Adventures in Walking Tour of China,' Sydney Morning Herald, (Women's Supplement), 17 October, 2.

Byles, M.B. 1938b, 'Through the Chinese Bandit Country: an Armed Guard with Umbrellas and

Towels,' Sydney Morning Herald, (Women's Supplement), 7 November, 2.

Byles, M.B. 1938c,'Sydney Woman's Isolated Camp: Headaches and Breathlessness in High Places,' Sydney Morning Herald (Women's Supplement), 19 December, 2.

Byles, M.B. 1939, 'The Black Dragon and the White: a Mountaineering Expedition to Western China,' The Bush Walker, 40-41.

Byles, M. B. 1940, 'Interest in Indo-China: Where France China and Japan meet.' Sydney Morning

Herald (Women's Supplement), 1 October, 3.

Byles, M. B. 1944, 'Bushwalking Babies,' Sydney Bush Walker, September, 2-3.

Byles, M.B. 1942, 'An Adventure in Loneliness,' The Bush Walker, 6, 35-36.

Byles, M.B. 1945, 'What is a Primitive Area?,' The Sydney Bush Walker, July, 5.

Byles, M.B. 1957, Footprints of Gautama, the Buddha, Rider \& Co, London.

Byles, M.B. 1962, Journey into Burmese Silence, George Allen \& Unwin, London.

Byles, M.B. 1963, The Lotus and the Spinning Wheel, George Allen \& Unwin. London.

Byles, M.B. 1965, Paths to Inner Calm, George Allen \& Unwin Ltd, London.

Byles, M.B. Scrapbook 1930-1960, ML MSS 5006, Mitchell Library, Sydney.

Cadzow, A. 2002, Waltzing Matilda's: a Study of Selected Australian Women Explorers 1840s-1940s, PhD Social Sciences thesis, Faculty of Humanities and Social Sciences, University of Technology, Sydney.

Callicott-Baird, J. and R.T. Ames 1989, Nature in Asian Traditions of Thought: Essays in Environmental Philosophy, State University of New York Press, Albany.

Coote, G. (director), P. Tait, D. Haslem, 1985, motion picture, A Singular Woman: The Life of Marie Byles, Australian Mountaineer, Author, Pacifist, Conservationist and Buddhist, Women's Film Fund and NPWS, Sydney.

Croucher, P. 1989, Buddhism in Australia: 1848-1988. University of NSW Press, Kensington

Cuc, L.T. 1999, 'Vietnamese Traditional Cultural Concepts of Human Relations with the Natural Environment,' Asian Geographer: a Geographical Journal on Asia and the Pacific Rim Special Issue: Eco-Consciousness in Asia and the Pacific, vol. 18 (1-2).

Dinh, T.H. 2003, 'Social Sciences and Biodiversity - Connections Between the Global the Local in Viet Nam.' International Social Science Journal 55 (4): 577-81.

Gerster, R. (ed) 1995, Hotel Asia: an Anthology of Australian Literary Travelling to the East, Penguin, Melbourne.

Goodall, H. 1996, Invasion to Embassy: Land in Aboriginal Politics in NSW 1788-1988, Allen \& Unwin in association with Black Books, Sydney.

Griffiths, T. 1997, 'Introduction: Ecology and Empire: Towards an Australian History of the World' (eds) T. Griffiths \& L. Robin, Ecology and Empire: Environmental History of Settler Societies, Keele University Press, Edinburgh.

Lawry, D. 1932, [untitled] in Sydney Bush Walker, April, 12.

Levins, C. and C. Macarthur, J. Ecob, R. Marni, and T. Gilbert. 1995, 'Ahimsa - Cheltenham Background Paper, Board Meeting no. 55, Agenda item 5j,' National Trust of Australia, NSW, 
Sydney, National Trust Archives, Sydney.

Lyall, G. n.d.'Buddhism and the Future of Humanity,' [online]. Available: www.buddhstcouncil.org/budfut.htm, Accessed 30 June 2006.

Massey, D. 2005, For Space, Sage Publications, London.

Meredith, P. 1999, Myles and Milo, Allen \& Unwin, Sydney.

Merton, T. 1966-1967, Section A: Correspondence: Byles, M.B. 1900-1979 file, Thomas Merton available at Merton Corpus and Bellarmine Merton Collection, www.merton.org/research/correspondence/z76b3.html, Accessed 3 October 2006.

Mills, S. 1993, Discourses of Difference: an Analysis of Women's Travel Writing and Colonialism, Routledge, London. First published 1991.

Monk, J. and V. Norwood (eds), 1987, The Desert is No Lady: South Western Landscapes in Women's Writing and Art, Yale University Press, New Haven.

National Trust of Australia (NSW), 2005-6, Marie Byles: a Spirited Life: a Celebration of the Life of a Committed Conservationist, Pioneer in Law and Buddhist, travelling exhibition, SeptemberMarch, Sydney, Central Coast, Bathurst, http://www.nationaltrust.org.au/properties/ahmisa/default.asp

Pearce, M. 1981, 'The Beginnings of Buddhism in Australia,' Karuna, February, 4-8.

Riley, R. 1992, 'Attachment to the Ordinary Landscape,' in Place Attachment, eds. A. Irwin and S. Low, Plenum Press.

'Review, Paths to Inner Calm,' Country Life, 1965, 28 January.

Ronalds, C. 2005, Marie Byles - A Reflection on her Life as a Legal Practitioner, Paper presented at the National Trust of Australia (NSW), Sydney, 13 September. Available: http://www.nsw.nationaltrust.org.au/chrisronalds.pdf

Said, E. 1993, Culture and Imperialism, Chatto \& Windus, London.

Spuler, M. 2003, Developments in Australian Buddhism: Facets of the Diamond, Routledge, Curzon, London.

Stephenson, I. 1999, 'In Joy and Affection: Walter Burley Griffin and the Stella James House' in Avalon: Landscape and Harmony: Walter Burley Griffin, Alexander Stewart Jolly and Harry Ruskin Rowe, ed. J. Roberts. Ruskin Rowe Press, Avalon.

Sugatananda, A. 1960, ‘The Purpose of the Buddha’s Teaching' World Buddhism, March, 3.

Tenko-San I. 1969, A New Road to Ancient Truth trans. Makoto Ohashi in collaboration with Marie Beuzeville Byles, foreword by M.B.B, Allen \& Unwin, London.

Terry, D. 1962, 'Road to Mandalay,' (Review of Journey into Burmese Silence), The Bulletin, 28 July, 40.

Tsomo, K. L. 1999, Buddhist Women Across Cultures: Realizations, State University of New York Press, Albany.

WAiB, n.d., 'Female Buddhist Scholars’ Available: http://members.tripod.com/ Lhamo/3schol.htm [accessed 25 September 2005]. 